\title{
INTERPRETING SOCIOSPATIAL FRAGMENTATION, DIFFERENTIAL URBANIZATION AND EVERYDAY LIFE: A CRITIQUE FOR THE LATIN AMERICAN DEBATE'
}

\author{
Alejandro Morcuende* \\ Universidade Estadual Paulista
}

\begin{abstract}
Similar to many concepts in Social Sciences, the concept of sociospatial fragmentation has been often misused, at times leading to significant confusion. In view of that, this article aims to critically review this concept through some of the principal works about Latin American cases. It brings into discussion that, from a critical perspective and compared with differential urbanization and everyday life, the concept of sociospatial fragmentation contributes to explaining the current relationships between space and society. Based on such an interpretive association of ideas, the study indicates correspondence to strong social and spatial tendencies: the chronification of the crisis of capitalism, the complete urbanization of society, the bankruptcy of modernity, and the fragmentation of everyday life. All that led to the conclusion that fragmentation is, fundamentally, a battle against the use-value of everyday life, which characterizes the present relationships between space and society.
\end{abstract}

Keywords: sociospatial fragmentation; differential urbanization; everyday life; Latin America.

\section{INTERPRETANDO A FRAGMENTAÇÃO SOCIOESPACIAL, A URBANIZAÇÃO DIFERENCIAL E A VIDA COTIDIANA: UMA CRITICA PARA O DEBATE} LATINO-AMERICANO

Resumo: Como muitos conceitos nas Ciências Sociais, o de fragmentação socioespacial apresenta um abuso que muitas vezes leva a uma confusão significativa. Por esse motivo, o principal objetivo deste artigo é criticar esse conceito a partir de algumas das principais propostas no debate latinoamericano. Isso para sustentar que, uma vez realizado esse exercício e colocado em relação ao da urbanização diferencial e da vida cotidiana, o conceito de fragmentação socioespacial contribui para explicar as relações atuais entre espaço e sociedade. A partir dessa associação interpretativa, destaca-se a correspondência de grandes tendências sociais e espaciais: a cronificação da crise do capitalismo, a completa urbanização da sociedade, a queda da modernidade e a fragmentação da vida cotidiana. Tudo para concluir que a fragmentação é, fundamentalmente, uma batalha contra o valor de uso da vida cotidiana, que caracteriza as relações atuais entre espaço e sociedade.

Palavras-chave: fragmentação socioespacial; urbanização diferencial; vida cotidiana; latino america.

\section{INTERPRETANDO LA FRAGMENTACIÓN SOCIOESPACIAL, LA URBANIZACIÓN DIFERENCIAL Y LA VIDA COTIDIANA: UNA CRÍTICA PARA EL DEBATE LATINOAMERICANO}

Resumen: Como muchos conceptos en las Ciencias Sociales, el de fragmentación socioespacial presenta un abuso que conduce, a menudo, a una importante confusión. Es por ello que el objetivo principal de este artículo es realizar una crítica de dicho concepto a partir de algunas de las más importantes propuestas en el debate latinoamericano. Ello para sostener que, una vez realizado ese ejercicio, y puesto en relación con el de urbanización diferencial y vida cotidiana, el concepto fragmentación socioespacial puede contribuir a explicar las actuales relaciones entre el espacio y la sociedad. A partir de ese esquema interpretativo se señala la correspodencia de grandes tendencias sociales y espaciales: la cronificación de la crisis del capitalismo, la urbanización completa de la sociedad, la quiebra de la modernidad y la fragmentación de la vida cotidiana. Todo para concluir que la fragmentación es, fundamentalmente, una batalla contra el valor de uso de la vida cotidiana, que caracteriza las presentes relaciones entre el espacio y la sociedad.

Palabras clave: fragmentación socioespacial; urbanización diferencial; vida cotidiana; Latinoamérica. 
Introduction

It is quite common that, in scientific and philosophical debates, many of the concepts meant to substantiate new knowledge end up not allowing it to happen. This takes place, in part, because these concepts often carry abundant inherited knowledge that, in one way or another, relies on them to explain things. That is an essential starting point when addressing a concept such as that of sociospatial fragmentation, i.e. a critical aspect thereof.

Critical is understood here as related to the act of discerning and enumerating the accumulated knowledge of a given concept - knowledge that prevents one from seeing what it really expresses ${ }^{2}$. It is a practice rooted in the modern tradition of subjecting all existing knowledge to the screening of reason, as a propaedeutic exercise when addressing a concept, a debate, or a subject matter.

To review socioespacial fragmentation in a critical way is thus the first task to do in order to give the concept the right weight regarding its explanation of the current state of relationships between space and society. The first question to be addressed is, then, which part of the knowledge included in the concept of fragmentation prevents one from knowing and apprehending it today.

This scrutiny is carried out through the nodes of a long-standing debate in Latin America, with socio-spatial fragmentation at the center. These nodes, composed by different authors, are chosen for their ability to set the pace and content of the debate from the 1980s to today, in different parts of the continent. Thus, some of the most common references have been selected, which have generated more debate based on important concepts in different Latin American countries; concepts such as the idea of isolation of the periphery by Santos, of self-segregation by Sposito and Góes, or the idea of dissociated segregation by Prevôt-Schapira, among other.

Having expressed such a critical point of view - an exercise that is always incomplete and never exhaustive, which should be in constant revision and enlargement-, the concept now can be explored without excessive bias. The present exploration will draw on Henri Lefebvre's Planetary Urbanization hypothesis formulated in $\mathrm{La}$ Révolution Urbaine in 1970. The theoretical exploration of sociospatial fragmentation will pivot on its association with the concepts of differential urbanization and everyday life.

The proposed criticism, and the association between its main three concepts, allow us to establish some limits from which the debate can evolve and expand. The limits

2 The term 'critical' derives from ancient Greek крıтıkóc [kritikós], which derived from кpíıс [crisis], and means not only "definitive phase of a disease" but also "to screen", "to distinguish", denoting the action or faculty to discern and separate one thing from another. proposed, first of all a) entail that fragmentation should be understood as a set of social, economic, political and cultural processes that coincide in time, such as the collapse of the project of modernity, the chronic crisis of capitalism, and the overcoming of the contradiction between city and countryside. Secondly, b) such processes give shape to the social and special order inherited from the capitalist counter-reform that began in the 1970s. Finally, c) that socio-spatial fragmentation is not only morphological, but essentially relational, since it is the mediating element in the current relations between space and society.

\section{A critical review of sociospatial fragmentation}

Those engaged in sociospatial fragmentation debates quickly realize its conceptual misuse and polysemy a common issue in Social Sciences. The concept of fragmentation, and all its derivatives, is used as a tool to explain the results and consequences of various processes, whether related to issues such as housing, transportation, security, or other fronts of urban life.

Below are some of the known contributions of the fragmentation debate which are necessarily linked to other concepts such as that of segregation, difference and inequality. Such contributions are not, of course, exhaustive, and other perspectives not yet considered shall be added in proper time. Some important absences will be resumed in the following section.

This article aims to present a set of contributions cited as references in most of the Latin American publications on fragmentation ${ }^{3}$, classified according to the explanatory concept in question, the processes through which such concepts are explained, the scale(s) into which they fit, and the case studies on which they draw. Once the outline of the concept is delimited, the interpretive framework that gives the present study the precise explanatory load will be established on the theoretical level and in association with other concepts.

In 1995, Laurent Vidal called attention to the misuse of the term sociospatial fragmentation - a term that gained popularity in the eighties, when neoliberal hegemony was already underway across the world; this counterreform ${ }^{4}$ of postwar capitalism (1945-1970), which is the neoliberal project, marked the beginning of what today is known as sociospatial fragmentation. Vidal, in

3 It should be noted that this article was written from Brazil, and therefore Latin America, within the scope of the FragUrb Project (2018/07701-8). That is why the critical views of fragmentation contained here is fundamentally limited to the Latin American debate.

4 Reference is made to a counter-reform because, since 1970, the dominant political and economic forces designed a new political-economic project based on the dismantling of capitalism arising from the antifascist victory of 1945, represented mainly in the welfare state. 
his article Les mots de la ville au Brésil, un exemple : la notion de "fragmentation ", drew on the verification, in the previous fifteen years, of profound changes in the great metropolises of both developed and developing countries - some of the changes were no longer covered by the industrial city "model" (VIDAL, 1995).

Vidal starts off from the nonexistence, also then, of a unique explanatory system of fragmentation in the Brazilian academy of the late twentieth century. What does exist is an explanation claiming that fragmentation and globalization go hand in hand. According to Vidal, what lies behind the term fragmentation for the Brazilian scientific community of the moment is, on the one hand, a breakdown of the urbanization model for Brazilian metropolises, which is characterized by a "new sociospatial segregation". On the other hand, there is a crisis of thought about the notion of city, since in the face of this new reality the traditional tools used to understand it do not allow a description and explanation thereof.

Vidal synthesizes into three the different approaches to the sociospatial fragmentation element: a) as a new type of sociospatial organization of the city, quoting from very different studies on habitat, urban voids, transportation, ruptures in the social fabric; $b$ ) description and explanation of the transformations in the social behavior of citizens, and c) epistemological consideration of fragmentation as a new paradigm.

Another reference for the present critical review is French-Argentine Marie-France Prévôt-Schapira. Like Vidal, she starts from an "urban crisis" that began in 1980 with the end of the conceived image of Latin American cities as urban spaces that maintain their unity, in comparison with the North-American city model (PREVOT-SCHAPIRA, 2001). A triple consideration on fragmentation is also noted here, as follows: a) the understanding of it as the end of a global operation, represented by Milton Santos's study Fragmented Corporate Metropolis, in which the fragmentation of the labor market, of the transportation systems, and of the involution of the center would occur as fragmentary processes (SANTOS, 1990); b) based on American Sociology, fragmentation is defined as the emergence of new centralities, in the same way as preconized by Vidal - globalization qualifies and disqualifies spaces according to how profitable and close they are from what were called global cities (SASSEN, 1991); and, c) fragmentation concentrates its efforts on the increasing complexity of this urban crisis, since it addresses not only global changes, but also new urban borders within cities (SMITH, 1996).

In Prévôt-Schapira's view, globalization develops separation logic in the city. With the fall of the populist social contract, fragmentary processes start off, namely: the withdrawal of the poor from private spaces, the rise of violence, and the fear of insecurity (PREVOTSCHAPIRA, 2000). These processes are explained through the concept of "dissociated segregation", which seeks to overcome the dual conception of urban space, understanding that tensions that used to occur solely between groups will come to bare within each social group (PREVOT-SCHAPIRA, 2001). The extension of such tensions leads she to affirm that fragmentation comes to offer explanations for "the multiple borders that divide space into a continuum that becomes impoverished", which also leads her to reject explanations based on the center-periphery scheme. All these contributions have been applied to the Buenos Aires case.

Fragmentation in Santos's study was tackled as the condition of isolation in which one lives, in which the variables that come into play are residential areas - one's place in the metropolis -, transportation and poverty. Santos lists the variables to be addressed: the State's role; income distribution; economic growth and crisis; city size; speculation and urban voids; corporate and fragmented metropolis; and government spending. Santos defines the fragmentary situation as a corollary, "as the poor become practically isolated where they live, the existence of a truly fragmented metropolis can be thought upon" (SANTOS, 1990, p. 99).

Emilio Duhau and Angela Giglia resort to the idea of urban orders to explain the passage from the Fordist metropolis - in which it was possible to impose a single order - to the current fragmented metropolises and postmetropolises - in which different orders coexist. Therefore, they draw on an idea that repeats from different points of view and for very different cities. For instance, the idea that the contemporary metropolis is constituted by a socially, culturally and spatially fragmented urban fabric (DUHAU, GIGLIA, 2016). That urban fabric would have exploded into fragments that operate in isolation according to the experience that the inhabitants have of the city. Those fragments, which they name cities, have their origin in the processes of metropolization in the Fordist era. In this way, they point to the end of the modern city, with a single urban order to which certain heterogeneity is integrated.

It is worth noting that Duhau and Giglia insist that these processes reach the whole world; they at least present cases in Europe, North America and Latin America, especially in Mexico City. The Latin American city would explain its fragmentation from the processes triggered after the economic restructuring and globalization of the 1980s: a) crisis of Fordist industrialization, b) rapid restructuring of the tertiary sector, c) production 
of new metropolitan centralities, d) generalization of the horizontal condominium modality, e) reform of the housing inventory in central and pericentral districts and, f) production of large homogeneous housing complexes - of social interest (DUHAU, GIGLIA, 2016).

These transformations would lead to a model of a fragmented city, in line with the description proposed by Borsdorf, which since the 1980s is understood as the principle of spatial organization typical of Latin American cities, characterized by a new form of separation that is no longer large-scale, where metropolises can be divided into large areas with their own social or functional characteristics - but in a much smaller scale - in which the socioeconomic elements disperse and mingle (BORSDORF, 2003).

Other contributions worth mentioning are those of scholars Maria Encarnação Beltrão Sposito and Eda Góes. The hypothesis that guides their work is that sociospatial fragmentation is a process underway also in middle cities, but with characteristics very different from those of metropolises - an object of analysis that was restricted until the beginning of their contributions.

Their study Espaços fechados e cidades, published in 2013, supports this hypothesis based on different authors' conceptions about fragmentation, as previously mentioned. In particular, they regard the process of sociospatial fragmentation as a post-segregation one, since the former would be a complexity of the latter (SPOSITO, GOES, 2013).

From there, special reference is given to the PrevotSchapira and Pineda's 2008 study in which they point out the three directions that studies on the concept of fragmentation have been taking, namely: a) public policies and governance of metropolises; b) transformations of globalization and new strategies of business management; and c) relationships, often contradictory ones, between social change and urban change (PREVOTSCHAPIRA, PINEDA, 2008). It is in this latter direction that Sposito and Goes conduct their research on closed spaces, in which they insist on the integration of the universal character of global processes - the particular feature of Latin American social formations - and the singularity of middle cities, which for this case are the cities of Marília, Presidente Prudente and São Carlos, all located in the state of São Paulo (SPOSITO, GOES, 2013).

These closed spaces are, for the authors, the script for the characterization of Latin American cities at the moment, in which two processes mark the tendency to fragmentation: a) the concentration of the poorest sectors in areas far away from the city center and with a deficient network of means of collective consumption, and b) a spatial concentration of the richest, also in areas far from the city center but well served in terms of urbanization (SPOSITO, 2019).

Among all these contributions, which as well drew on many others, some consensus or emerging concerns at least from the nineties to the most recent publications - stand out. All of them are relevant issues to consider in this critical scrutiny of the term fragmentation.

Today the term fragmentation is used to define one, or several, social process(es) of different natures. It is also used to determine an alleged complexity of segregation. At the same time, it is associated with the emergence of a new type of city, which can be found in Latin America, or in the United States, or may even reach global proportions. Finally, the term fragmentation, in recent decades, would find its place in Urban Studies, thus being considered a paradigm. This polysemy creates a great confusion that only manages to blur out everything that the term, now a concept, has helped to explain. Only constant critical studies and confrontation with reality can clear out doubts and mark the boundaries of what can and cannot be explained by means of that concept.

\section{An interpretive scheme}

This section introduces the theoretical consideration of the concept of sociospatial fragmentation based on the framework of Lefebvre's Planetary Urbanization hypothesis, which acts as the main explanatory vector of the current relationships between space and society. It is a hypothesis that centralizes the debate today and manages to bring together the most pioneering contributions in Urban Studies (BRENNER, 2018). It will be argued that a debate on fragmentation is not possible without considering the overcoming of the contradiction between country and city.

In line with the abovementioned idea, the critical reflection presented so far demonstrates the necessary association of the concept of sociospatial fragmentation with at least two other concepts, so that the former is capable of explaining the latter. Sociospatial fragmentation will finally be defined as a battle against the use-value of everyday life, as regards the capture and domination exerted by abstract space over differential space, once the concept of fragmentation alone is not fully explanatory. Thus, the concepts of differential urbanization and everyday life will be developed and interwoven one with the other, until a definition of sociospatial fragmentation can be attained.

\section{Differential urbanization}

The processes of sociospatial transformation under capitalism can be summarized in three core moments of urbanization, which are mutually constitutive and 
dialectically intertwined (BRENNER, SCHMID, 2015). The first one is a moment of concentrated urbanization, typical of industrial capitalism, in which the concentration of capital and people in metropolitan agglomerations increases, at the same time that new nodal concentrations emerge and progress. It is the moment of urbanization processes exclusive of cities and metropolises.

The second moment - extended urbanization - refers to the transformations in the territories and landscapes beyond agglomerations, which continues to be one of the engines of the urbanization process. Extended urbanization $^{5}$ explains the urban operationalization processes of places and territories located beyond specific forms of 'cityness'. This is a process that takes shape in the areas of influence of metropolises and cities, in smaller towns, in the extensive infrastructure networks that cross the territories, in the operationalization of wild territories, among others.

Finally, Brenner and Schmid's proposal includes the processes of differential urbanization, implying a rupture with the inherited social and spatial order - which is diverse in every sociospatial formation for acting on a radically variegated existing space; the production of new urban potentials for the appropriation of existing urban configurations; and the creation of new forms of urban space (BRENNER, SCHMID, 2015).

Differential urbanization synthesizes, alongside other two moments of urbanization, the dynamism with which the capitalist forms of urbanization operates today, under a logic of innovation and obsolescence of these forms. It also frames all urban processes - whether concentrated and widespread -, which are faster and more changing today, accelerating at the same pace as that of the contradictions of capitalism in crisis. These contradictory processes - of acceleration and stagnation -, in the relationship between space and society, are territorialized and opposed to everyday life, making it more difficult, more unfair, more dangerous, and less livable.

In differential urbanization - moment of a "historically specific process of sociospatial transformation" in which a systemic and chronic crisis of capitalism could be involved, as known so far -, the dynamics synthesized by Lefebvre can be considered in terms of an implosionexplosion relationship (BRENNER, SCHMID, 2015, p. 169). In other words, it refers to continuous and constant processes of sociospatial restructuring in and beyond agglomerations - more and more beyond in fact alongside the historical moment, i.e. this current phase

5 That moment of extended urbanization has a clear relationship with the counter-urbanization process defined by Brian Berry in 1976 and the debates about compact versus diffuse city. of the capitalist mode of production, inaugurated in the 1970s.

The idea underlying the discussion so far is that the mere fact of the existence of a moment, such as that of differential urbanization defining a continuous impulse of sociospatial restructuring, opens the door to fragmentation, where any planning possibility might suit.

The reflections hitherto proposed will move forward by establishing an initial dialogue between two of the most complete forms of spatial thinking. This is done on the conviction that from an association between these forms, solid insights can be expected for the scrutiny of the current state of urbanization. Both are proposals with clear holistic commitment, and a method orientation based on relations, totality, inequality and crisis (MORCUENDE, 2018).

There are clear potential correspondences - that is, with the capacity to, in association, offer theoreticalmethodological insights - between Lefebvre's Planetary Urbanization hypothesis, coupled with subsequent developments of the Urban Theory Lab, and the System of Objects and Actions put forward by Santos.

Santos argues that the present of a society and geographical space is related to a technical system "involving ways of producing energy, goods and services, ways of relating men to each other, forms of information, forms of discourse and interlocution" (SANTOS, 1996, p. 177). For their part, recent contributions deem the technical innovations and the industrial restructuring of several sectors as processes of this permanent sociospatial restructuring in a kind of logistic urbanization that is also differential urbanization (ARBOLEDA, 2016, 2020). These ideas are in line with the description provided by Santos, quoting from Lojkine, of the current technical system as a "flexible, self-regulating system of multifunctional machines, using material and immaterial (informational), decentralized and interactive means of circulation (networked telematics)" (SANTOS, 1996, p. 177).

Differential urbanization has been defined as a constant process of sociospatial restructuring, of a set of urbanization processes of explosion/implosion moving between innovation and obsolescence. In developing the functioning of the System of Objects and Actions at the present time, Santos supports that "space is always changing its physiognomy, in its physiology, and its structure, in its appearances, and in its relations" (SANTOS, 1996, p. 213). Thus, it is just like "objects, which even being recent are quickly exchanged, revalued or devalued" (SANTOS, 1996, p. 213).

One final assessment links Planetary Urbanization with Santos's explanation of globalization. The basis of 
globalization, and of transformations in the production of space, is explained by these three elements of unicity: techniques; time; and the engine of economic and social life. It could be established that the unicity regarding technique, in which contemporary and other techniques coexist, is a sign of the possibility of Planetary Urbanization, of the global reach that the capitalist mode of production can have. It is also when the three constituent moments of urbanization coexist, and in which rhythms and intensities of different order occur throughout the Planet, as Santos points out: "today, thanks to the phenomenon of networks and the spread of modernity over the territory, it is known that new capital spreads more widely, more deeply, and more quickly in the countryside than in the city" (SANTOS, 1996, 322).

This paper does not seek to draw any parallelism here, nor to point out contrasts between the two proposals. These have different origins - despite Santos's French education, and the great French influence that exists in the University of São Paulo and in Brazil in general - and evidently develop from different points of view, although sharing strong philosophical roots. Rather, the paper seeks to draw attention to the explanatory potential of the association of the two most complete systems of thoughts about space and urbanization. Only in this way, by returning to the classics, will these two proposals be able to transform insights into certainties as far as the term fragmentation is concerned.

In the last pages of Lefebvre's 1974 book La production de l'espace, he developed the concept of differential space which, obviously, was grounded on that differential moment of urbanization. Thus, if urbanization is differential, it is partly due to the different expressions of the urban struggle, which, in a movement of contradiction, provides both clarification and blurring. Additionally, on the one hand, it is worth mentioning the opening of disputes and competition at all scales - the war of places, quoting from Santos.

There can be mentioned not only the struggles for the subsistence - which E. P. Thompson ${ }^{6}$ so brilliantly developed - of living conditions, which make their way into greater scales of the urban, but also the competition that, from hegemonic objects, arises between valued and undervalued spaces. It is there that the differentiation of space begins - in the deepest Social and Territorial Divisions of labor, creating spaces that are more specialized and more heterogeneous, and with some borders - delimitations between one and the other - that

6 These struggles for subsistence are framed in analyses of the transition from feudalism to capitalism, started mainly by the Communist Party Historians Group, with references such as Maurice Dobb, Rodney Hilton, among others. In that context, Thompson developed his most complete writings complied in Customs in Common, in which the author's central aim was to examine the relationship between economics and values. are sharper (SMITH, 1984).

In between refutations, there is also the heat of debating. Differential space, which results from the contradictions of abstract space - the conceived space of planning, above all - also presents a horizon of possibilities. Such an exercise is both theoretical and political $^{7}$ (Lefebvre, 1970, 1974). It is an idea well followed by contributions that, in an attempt to reorganize the mining sector, point to the emergence of new political subjects of production after the demise of the peasantry (ARBOLEDA, 2017).

\section{Everyday life}

Addressing an issue such as that of everyday life implies mobilizing such a set of concepts, of disparate natures - a challenge for any researcher. One of the fundamental references in that regard is, without a doubt, Lefebvre's complete work. Everyday life, initially thought of as a philosophical category, today is the domain of different disciplines that, as warned by Lefebvre, have contributed to fragmenting it already from the thought alone. It could not be otherwise in Social Sciences, which are at the same time fragmented and fragmentary.

The philosophical, theoretical and empirical burden that the concept of everyday life takes on is overly heavy. Thus, the exercise of constant abstraction and concretion proves indispensable. The debate in question is held under the auspices of three main elements: modernity, place, and practices - doors that in turn lead through endless paths: philosophy, language, sociology, geography, aesthetics, avant-garde.

Here, everyday life is considered a dimension of the urban that spins the social organization, where the differential character of space (dispute) unfolds, bringing together different scales and times. Additionally, it is characterized by the concentration-separation pair and by the repetition-transformation pair, in which possibilities are opened from the urban - a utopian impulse that may well reinforce the Planetary Urbanization phase.

It can be affirmed that everyday life is a dimension of the urban on the grounds of what Lefebvre advocated in $L a$ production de l'espace. Spatial practices, representations of space and spaces of representation form part of such production of space, which translates into a perceived space, a conceived space and a lived space (LEFEBVRE, 1974).

Brenner and Schmid continued Lefebvre's work, resorting to new theoretical-methodological tools to understand the urban, and made use of another triple set:

7 Sided with induction and deduction, Lefebvre situates transduction, the possible construction of a virtual object. 
spatial practices, territorial regulations, and everyday life. These three elements should be considered constituents of the three moments of urbanization mentioned in the previous section (BRENNER, SCHMID, 2015).

The consideration of the urban dimension is somehow related to the existing opposition between abstract space and differential space, also commented on in the previous section. Abstract space is characterized as homogeneous, hierarchical and fragmented, and is opposed to differential space, which is heterogeneous, alluding to the difference that homogeneous intends to mask and daily can make emerge (LEFEBVRE, 1974; KINKAID 2020).

In terms of the issue of time concerning everyday life, it is important to make a first distinction. At the theoretical-conceptual level, 'daily' cannot be associated only with the sum of the different activities that an individual performs in a 24-hour period; but, otherwise, in the methodological approach to be addressed later.

Within those 24 hours are at least historical time, social time, and individual time. Lefebvre worded it as follows: "the history of one day encompasses that of the world and that of society" (LEFEBVRE, 1971[1968], p. 4). Those are three times that, of course, by their scale, have a different level of particularity, where it is worth pointing out at least the current historical time, here associated with the supposed breakdown of modernity; social time, clearly determined by the first major crisis of counterreformed capitalism of the 1970s; and individual time, which gives rise to different and contradictory forms mediated by the other two times. The reflection around everyday life implies, of course, a reflection on the present time, on the coordinates in which our historicity moves.

Finally, the three times will be specified in a context, under the historical-political and cultural conditions in which a fact is involved. Everyday life can also be understood here as a dimension of mediation, hence "places, from this point of view, can be seen as an intermediary between the world and the individual" (SANTOS, 1996, p. 314).

Everyday life also encompasses two major tensions. The first one is formed by concentration and separation. On the one hand, there is also what Santos called the convergence of moments, which involves at the same time a command of great actors that dominate that universal real time, and actors that do not have the capacity to command and therefore are subordinated to it (SANTOS, 2000). This convergence implies concentration and harmonization of time by means of the command exercised with the times provided for in urban planning itself in terms of representations of space. Although those guidelines may be diversifying with the help of technique, today the times of labor, leisure and reproduction are more rigidly defined.

Separation results, on the other hand, from the breakdown of individual time that both historical time (the breakdown of modernity) and social time (capitalism in crisis) exert on the former. It refers to the alienation typical of postmodern times, of the supposed overcoming of the modern project. This issue will be addressed in the next section, as the first fragmentary process of our time is inherent in this issue.

The second tension that everyday life encompasses is that of repetition and transformation. As Lefebvre did in the first pages of La vie quotidienne dans le monde moderne, using James Joyce's Ulysses as a starting point, everyday life is often associated with events that occur within 24 hours of a day. Of these events, the majority are scheduled and repeated activities, which follow each other day after day. These refer to the linear time that rationality imposes, through some fixed points - which concentrate the spaces of work, leisure and home - and the existing flows between them, i.e. mobility. It is the image associated today with the urban.

Routines also make room for innovation, which is defined as the alteration of linear times, increasingly interwoven with the cyclic times of nature. The unexpected can alter all times, and even though the individual is the one most exposed to the routine and the unexpected, it is from the association between this and social time that the greatest of all transformations arise. In this regard, Brenner and Schimd argue that

urbanization is precisely the means and the expression of such a collision/transformation, and each configuration of urban life is powerfully shaped by the various social, political and institutional forces that mediate it (BRENNER, SCHMID, 2015, p. 172).

It is also in it that another characteristic of everyday life unfolds, one that can be reinforced by the Planetary Urbanization paradigm being analyzed. In the first pages of La Révolution Urbaine, Lefebvre shows an essential letter for the scientific thought about the urban, as well for the political action of everyday life. In presenting the exercise of transduction, the reflection upon the possible object - which therefore does not need to exist - is making a double invitation to thought and action. This is about looking at the virtual object, which is the complete urbanization of society, and thinking of the possibilities that open up in that novel scheme of social relations.

If purely theoretical reflections are added to the analytical debate, everyday life would necessarily have to be reconsidered, with attention, of course, to the 
theoretical lines defined above. In this regard, at least two debates can be thought of: in the first place, that of the analytical dimensions of everyday life - how to bring to light and out of anonymity all dimensions of everyday life? By which analytical categories to decipher everyday life at the present time? And in the second place, the most recurrent questioning in this matter, along with methodology, is, once such dimensions come to view: how to capture them?

It is time, then, to define some dimensions and minimum methodological orientations to unravel the social relationships incorporated by differential space and concealed by abstract space - i.e. planning. Lefebvre established at least the following components of everyday life: space, time, pluralities of meaning, symbolism, and practices (Lefebvre, 1968). Among such components are, on the one side, those that can be apprehended from the theoretical dimension - from the considerations previously presented - and, on the other side, those that need to be included in this double methodological debate.

The present discussion starts from the empirical dimensions defined in the FragUrb Thematic Project in which researcher Lefebvre take part. These dimensions are: housing, labor, consumption, leisure, and mobility. The analytical definition of the empirical dimensions of everyday life must allow them, together, to integrate today's social organization. In other words, these dimensions must not only be able to capture all the routine events contained within 24 hours of a day, so individual time will be defined, but also be able to detect the constituent elements of everyday life typical of historical time and social time.

Here, a questioning can be raised. The simple definition of the dimensions of everyday life allows to organize the endless practices that occur in one day, that is, such dimensions capture the expression. However, this depth, this thread of today's social organization that is pursued is hidden in the social relationships that facilitate one or the other practices, and that often hide in that kind of fetish that is abstract space (Lefebvre, 1974). Analytical efforts must therefore be directed to a definition of the relationships between those empirical dimensions of everyday life, according to the times, rhythms, vectors, contents, and scales of each dimension ${ }^{8}$.

\section{Sociospatial fragmentation}

The definition of the third concept of the interpretive

8 Somehow the aforementioned Fragurb Project make such efforts, with investigations organized by thematic work plans that crosscut all the dimensions that empirically define everyday life in said project. scheme herein proposed is discussed below. First of all, the limitations considered do not allow making fragmentation a concept that is entirely explanatory for the present in order to, secondly, show some certainties that may offer clues to further develop the theoreticalmethodological reflection as far as sociospatial fragmentation is concerned.

Based on the critical reflections in the initial pages, some elements of the concepts can be isolated in order to help reduce confusion over the term, seen from today. This is what is expected from a critical review. Is sociospatial fragmentation the current paradigm from which the field of Urban Studies organizes its way of seeing its object of study? Is it a new type of city typical of a particular sociospatial formation? Is it, perhaps, the accentuation of segregation processes? Are new centralities those that make way to sociospatial fragmentation?

This is not a paradigm if one understands the set of knowledge that organizes what is known about a certain object at a given time. Although fragmentation indicates an inflection, the paradigm to explain such an inflection is that of Planetary Urbanization, coupled with the set of concepts and hypotheses that it brings together. When it comes to the scrutiny of the relationships between urbanization, everyday life and fragmentation, it is argued that there is a causal link between the complete urbanization of society - the assimilation of the country by the city - and sociospatial fragmentation. If this is so, the cause cannot be paradigmatically subordinated to the effect.

The debates around segregation in Social Sciences are extensive and complex. The definition of segregation processes has not found a clear consensus over the years, hence the debate. There are endless definitions, themes, explanations, and empirical approaches. What they have in common is their intention to explain the dynamics of industrial capitalism, one in which the distribution of homogeneous uses was clearly defined, thus transposing the spatial heterogeneity of commercial cities. The consensus today encompasses the analysis of urban areas that are not so clearly defined nor homogeneous a fact that would justify the term fragmentation.

Due to the obsession of most positivist visions of Social Sciences with measuring all things, partially because of the data capture provided by the GIS technology to Geography, today it seems that everything should be amenable to cartographic representation. In current Urban Studies, an excessive weight has been added to the visible, surely inherited from Geography and owing to the fact that it is a discipline with a clear spatial component.

However, in a flash of insight, sociospatial 
fragmentation is hardly capturable empirically as such. What is really to be built, and now fragmentation occupies a key place, are theoretical-methodological explanations of the current relationships between space and society at a time of great transformation of the capitalist economic structure. Thus, the concept of sociospatial fragmentation should, first of all, be a clear theoretical category, rigorously defined, in order to initiate consistent empirical analyses towards its measurement and cartography. It is not, for the time being, a drawable concept, nor recognizable in the built environment, even though there are numerous clues to decipher it.

Sociospatial fragmentation has, as a concept, a great capacity to promote ideas and debates thanks to its long journey, the different visions and contributions offered, and because it approaches a key and recurring issue in urban debates: the sociospatial organization of contemporary societies. Hypothetically, fragmentation helps define the current relationships between space and society, at a time of capitalism in crisis, also marked by uncertainty.

If that is so, then a phenomenon of global reach is being witnessed, and it is not limited to a specific area of the world, at a time when, as argued above, the old north-south, first-third world boundaries no longer help explain virtually anything in a reality that does not respond to binarism. Thus, the term cannot refer solely to a type of city, or a settlement typical of a region of the world, as some authors have pointed out. So, how can the term sociospatial fragmentation be theoretically and analytically delimited?

Therefore, sociospatial fragmentation can be regarded as a theoretical element with the capacity to elucidate the current state of relationships between space and society - relationships that were radically transformed in the 1970s, coinciding with one of the greatest counterreforms of capitalism, assuming the end of the anecdotal years of sustained growth of postwar capitalism. This aligns with some of the main authors who have contributed to the fragmentation debate.

In his hypothesis presented in 1970, Lefebvre pointed out a moment, and developed it years later, in which abstract space - the space produced by capitalism contained a destructive force of urban life from the means supposedly intended to create or recreate it (Lefebvre, 1974). He was clearly referring, on the one hand, to neutral hierarchical space and, on the other, compromising the role of planning, this destructive force of the life to which it should give rise. The fragmentation debate also points to a debate about planning, a new exercise from a critical perspective, which has been long postponed 9

Lefebvre addresses, therefore, a set of contradictions. The original one is that existing between abstract space and differential space. Fragmentation begins with homogenization. It arises when abstract space - the conceived one - sequesters concrete space - the lived space, that is, when everyday life is also fragmented.

From this point, i.e. from the contradiction that grows in differential urbanization, other fundamental contradictions develop. Three of them can be pointed out here. In the first place, one could not speak of a critical phase - space as a black box that is incomprehensible (Lefebvre, 1970) -, nor would there be a search for strong explanations for the current state of urbanization in the world without the fragmentation underlying Social Sciences, without the separation to which the breakdown of modernity leads, and without the division into which space is produced under the capitalist mode of production: perceived, conceived and lived. All of them are lost units that need to be recovered. Without them, the contradictions of the mode of production will continue to be expressed in and through space, despite the fact that the characteristics, depth and severity of this fragmentation make it more or less perceptible or liveable.

From the contradiction between abstract space and differential space, the question of difference emerges. That contradiction has always existed in the history of capitalism; however, in the current phase of the capitalist crisis the distance between abstract space and differential space is greater and comprises more contradictions which are even more unbearable. The extent of this contradiction can be assessed by focusing attention on how little the difference imposed can produce something new. The more difference unable to produce change concealed difference -, the more contradiction and the greater distance between abstract space and everyday space.

This leads to a consideration of fragmentation as a set of social, political, economic and cultural processes from which the inherent difference of urban society does not produce anything, given that the first logic that is imposed, that of separation, prohibits that in lived spaces such difference be expressed and conflicts be perceived, a necessary condition for such processes to be expressed (LEFEBVRE, 1974). When difference is perceived and generates conflicts, space becomes

9 The critique of urban planning coincides, in large part, with the reorganization plans of Paris in the late 1950s and throughout the 1960s. That is the moment when the writings of Lefebvre (1968, 1970), Lokjine (1972) and Garnier (1976) are published. It is a debate that, although hardly ever interrupted, has never counted, with the exception of May 1968 in Paris, with a pyrrhic repercussion; even more today with the consensus of the New Urban Era dominating Urban Studies, and the management and policies of the city. 
relational, conflicts are established, and in that clash something new is created.

When fragmentation becomes a discussed topic, it is because something, at some point, has lost its unity. Some tensions have been noted above, and they lead - alongside those fragmentary processes - to the breakdown of the unity of life. Therein lies the fundamental insight to be explored. Fragmentary processes may be delving into the breakdown of the city, of the apparent, of the visible, but above all they seek to explore the battle against the use-value of everyday life, which is fundamentally fragmentation, as an explanatory characteristic of the relationships between space and society in the present.

What are these social, political, economic and cultural processes of sociospatial fragmentation? It is timely to list five major tendencies that make up sociospatial fragmentation. It is important to note that these six tendencies exceed the apparent object that Urban Studies should attend to. However, the exercise that is being developed here is based on the conviction that, for the explanation of the current relationships between space and society mediated by fragmentary processes, it is necessary to delve into phenomena that usually did not relate to urbanization processes.

These great tendencies are: a) the breakdown of modernity and the crisis of capitalism, b) the overcoming of the contradiction between country and city, c) the overcoming of the center-periphery logic, d) the transformations in the Social and Territorial Divisions of labor, e) the concentration of landed property, and f) the gradual erosion of the collective subjects that have until then operated. All these tendencies translate into social, political, economic and cultural processes and, if they have something in common it is that they end the inherited social and spatial order, giving rise to new configurations.

If one seeks to clear a path towards explanations for the concepts of urbanization, everyday life and fragmentation, in which the latter is defined as the rupture of everyday life, one must start by defining the historical time in which that life develops. The different times that everyday life encompasses have been noted above. Like many thinkers have pointed out, from very different perspectives, a historical inflection can be seen in the 1970s. There begins a capitalist counter-reform that also starts a production of space, through a set of transformations. It is important to turn to cultural critic Frederic Jameson to analyze these processes according to his cultural logic (JAMESON, 1998).

Even today, already in a new phase of restructuring of capitalism marked by a deep, permanent and chronic crisis, one is not in a position to offer an explanation for the transformations that began in 1970 and gave rise to our present. And that happens, in large part, due to the blind field in which space, urbanization and the relationships between space and society have been constituted, caused by a proliferation of supposedly different objects of study, methods and entrenched methodologies as an end in themselves.

Based on all the literature review carried out not only by Jameson but also by Gyorgy Lukács or Guy Debord on the cultural logic of late capitalism (MANDEL, 1972), which is postmodernism, the question of the death of the subject can be brought about. If the modernist aesthetic is in some way organically linked to the conception of a unique self and private identity; in postmodernist aesthetic there is only imitation - pastiche - since there is no possibility of creating universal narratives (JAMESON, 1998).

Imitations reside in, and by, the spectacle. The death of the subject comes about when great explanations fall, and everything life lacks is to be found within the spectacle (Debord, 1967). If modernity is able to create the subject through activity, postmodernity alienates him/ her through contemplation; that is the core of the society of the spectacle. This is where separation appears: the impoverishment of lived space, compartmentalized areas of life, and the consequent loss of the unitary aspect from society (JAPPE, 1993).

There is, therefore, a correspondence between the advent of postmodernity, the chronic capitalist crisis, and the loss of normative Social Sciences, which help to draw the outline of the historical time of the present.

The second major tendency is the overcoming of the contradiction between country and city, as Marx defined:

\footnotetext{
the foundation of every division of labour that is well developed, and brought about by the exchange of commodities, is the separation between town and country. It may be said, that the whole economic history of society is summed up in the movement of this antithesis. We pass it over, however, for the present (MARX, 1975 [1867], p. 429).
}

What connection does this supposed overcoming have with sociospatial fragmentation? First, and again in a flash of insight, sociospatial fragmentation begins when the clear border between country and city yields. From that, homogeneous, neutral, hierarchical, abstract space begins to prevail, where the clearly established boundaries between the uses of industrial capitalism fall. Homogenization makes way for fragmentation (Lefebvre, 1989). Once the contradiction between country and city has been overcome, the entire space is 
likely to be urbanized - with its different processes and forms -, owing to the capitalist mode of production and the contradictions that generate ruptures, as previously mentioned.

On the other hand, overcoming this contradiction also warns of a profound modification in the centerperiphery scheme, in which the center and the periphery - centralization and peripheralization - are resolved in a more complex way. That relationship is today mediated by the fact that the new feature of urbanization is that centrality is becoming general, omnipresent and yet ephemeral (SCHMID, 2014, p. 68).

As a result, the first idea to work with is that of centrality being at the same time omnipresent and ephemeral. For now that idea is developed at the intra-urban level, and the exploration of the different scales in this matter is pending. Such omnipresent character is manifested in the existence of old areas considered peripheral with center characteristics, which in some cases lead to the loss of the peripheral status, which could be termed as an interstitial space, that is, a space located between two bodies. Is this a new periphery?

However, it is also an ephemeral centrality, since there are peripheries that manage to escape the center. The idea behind this escape is that the center is no longer defined today by its geographical position, but by its position in networks, borders and differences (Schmid, 2014), that is, by its ability to mediate between spaces at different scales, by the privilege that the conceived space gives to spaces, and by its ability or inability to translate differences into conflict, and to make something new emerge out of conflict.

Both the overcoming of the country-city contradiction and the reconfiguration of the relationships between center and periphery engender consequent restructuring in the social and territorial divisions of labor. To look at them analytically can help understand how the territory is being used, what is inherited, and what is changing (Santos, 1996; Silveira,2009). Although the latter is the variable that adds complexity to the social organization of the present, landed property is no less clarifying as a process that leads to fragmentation. Reference to landed property leads, at least, to the (re)opening of debates on land value, income, freedom, land as capital, living standards, financialisation of land, and inequalities of wealth (DOMENECH, 2004; RYAN-COLLINS, LLOYD, MACFARLANE, 2017). All of them, processes that nobody will deny, can have explanatory capacity in the rupture of the inherited social and spatial order. Finally, these two processes are closely linked to the shunned debate on social classes, which must be urgently rescued for the purpose herein discussed.
The spectacle and the death of the subject, a more complex Social Division of Labor, and a concentration of real property, not only force the researcher to take inequality as an element of method but also have caused major changes, in a fragmentary key, in social structures of contemporary societies (WRIGHT, 1997, 2015). Thus, the "class for itself" debate needs to be addressed, also with the emancipatory possibilities that, on the horizon, allow a glimpse of Planetary Urbanization.

Here, only some of the references that need further investigation were noted. It is necessary to delve more deeply into the relationships between these processes, in their causal relationship with sociospatial fragmentation, and their hierarchy in an interpretation of the current relationships between space and society.

\section{Conclusions}

It should be made clear here that this review did not intend to demonstrate anything, nor to find a comprehensive explanation that exhausts the reflection on urbanization, everyday life and fragmentation. On the contrary, the intention here was to provide insights that, after the effort of ordering them, may trigger some more questioning to guide and continue the reflection on the intended debate.

The first finding, which today constitutes the main focus of this paper, is the correspondence that exists between different powerful social processes - the crisis of capitalism, the complete urbanization of society, the breakdown of modernity, and the fragmentation of everyday life. Despite the clarity of this correspondence, developed in the above pages, there are still some friction points that generate issues about the present moment and finally indicate the way forward regarding the question raised here.

Some issues that arise, after some critical thought on the term fragmentation, also represent an inexhaustible process that must continue to guide the construal of the term. What can be affirmed is that a critical reflection upon it is the first step to be taken regarding the great deal of theoretical-methodological efforts devoted to the topic of fragmentation, and so it will keep being carried out by means of the main contributions to Social Sciences.

The first element to keep in mind is that of scale (BRENNER, 2019). Is fragmentation a process of Latin American metropolises? Does it go beyond the metropolis and the Latin American social formations? The critical reviews on fragmentation so far have been conducted mainly by Latin American authors or by researchers of Latin American studies. However, the debate on 
segregation, the outset of what is being debated today, is a classic debate on Social Sciences, and even more so on Urban Sociology, dating back from its institutionalization in the late 19th century at the University of Chicago.

The central argument of this and further critical review is that, without the social, economic, cultural and political processes that lead to overcoming the countrycity contradiction, one cannot speak of sociospatial fragmentation. From these processes, when the clear boundary between country and city collapses, is when fragmentation makes its way, from the three constituent moments of urbanization: concentrated, extended and differential. Rather than focusing efforts on dating the birth of something similar to sociospatial fragmentation, what is intended here is to insist on the idea that today fragmentation occurs through novel social, political, cultural and economic processes. This backbone idea provides a clue about the first issue raised here.

Based on the dichotomy between morphology and relationships, the second questioning was established. Often, debates on segregation and fragmentation are associated with the search for signs, marks, borders, associated with the enormous weight of the visible in some Social Sciences, and in particular in Geography and Urban Studies. What is argued here is that sociospatial fragmentation is not just a process that occurs through physical ruptures, in a flat approach to these concepts.

The topic is much more complex today and it becomes even more complex in branched Social Sciences that cannot really bring fragmentary social relations to the surface. That is why, in the face of morphology, what is pursued are the social, cultural, economic and political processes that currently break with inherited social and spatial orders. Fragmentation is, therefore, not only morphological; it is eminently relational, it resides in the contradictions - today accentuated and chronified between space and society.

This issue leads directly to the unicity debate. If one speaks of fragmentation and ruptures, one must necessarily invoke unicity and continuity. But what exactly has been ruptured? What unicity has been lost? Is it possible to recover some sort of continuity? It is difficult to find something similar to unicity in the history of cities; not even when walls clearly drew the beginning and end of the city. There can be found cities that are more or less homogeneous in their social conditions, more or less heterogeneous in their functions, and more or less cohesive.

When situating this issue in time and space, on a small scale, it can be pointed out, first, that the continuity that has disappeared is the historical tendency of the contradiction between country and city - a contradiction that has outlined, to date, the economic history of human societies, be that history as it has been. The urban at present gathers a large part of the questions and answers to the object of discussion in these pages. It provides the explanatory keys to the present. And secondly, there is a rupture when the inherited social and spatial order be that as it may be - succumbs. That is why the 1970 s is the starting point of correspondence to these great tendencies that query and mine the social and spatial order really existing at present. 


\section{References}

ARBOLEDA, M. (2016). In the Nature of the Non-City: Expanded Infrastructural Networks and the Political Ecology of Planetary Urbanisation. Antipode, 48, 2, 233-251.

ARBOLEDA, M. (2017). La naturaleza como modo de existencia del capital: organización territorial y disolución del campesinado en el superciclo de materias primas de América Latina. Anthropolohica, n³8, 145-176.

ARBOLEDA, M. (2020). Planetary Mine: Territories of Extraction Under Late Capitalism. London and New York: Verso. BORSDORF, A. (2003). Hacia la ciudad fragmentada. Tempranas estructuras segregadas en la ciudad latinoamericana. Scripta Nova. Vol.VII Núm. 146.

BRENNER, N.; SCHMID C. (2015). Towards a new epistemology of the urban? City, 19: 2-3 , 151-182.

BRENNER, N. (2018). Debating planetary urbanization: for an engaged pluralism. D Society and Space, Vol. 36(3), 570590.

BRENNER, N. (2019). New urban spaces. Urban theory and the scale question. Oxford: Orxford University Press. DEBORD, G. (1967). La société du spectacle. Paris: Buchet/Chastel.

DOMENECH, A. (2019) [2004]. El eclipse de la fraternidad. Barcelona: Akal.

DUHAU, E.; GIGLIA, A. (2016). Metrópoli, espacio público y consumo. México: Fondo de Cultura Económica.

JAMESON, F. (1998). The cultural turn. London: Verso.

JAPPE, A. (1993). Debord. Pescara: Edizioni Tracce.

KINKAID, E. (2020). Re-encountering Lefebvre: Toward a critical phenomenology of social space. D Society and Space, Vol. 38(1), 167-186.

LEFEBVRE, H. (1971) [1968]. Everyday life in the modern world. New York: Harper \& Row, Publishers.

LEFEBVRE, H. (1970). La Révolution urbaine. Paris. Anthopos.

LEFEBVRE, H. (1974). La production de l'espace. Paris: Éditions Anthropos.

LEFEBVRE, H. (1989). Quand la ville se perd dans une métamorphose planétaire. Le Monde diplomatique, 1989. Disponivel em : https://www.monde-diplomatique.fr/1989/05/LEFEBVRE/41710. Acesso em: 9, dezembro, 2019).

MANDEL, E. (1972). Der Spätkapitalismus. Versuch einer marxistischen Erklärung. Frankfurt: Suhrkamp Verlag.

MARX, K. (1975) [1867].El Capital, Vol. I. México: Siglo XXI.

MORCUENDE, A. (2018). Rupturas Urbanas. Aproximación a las relaciones entre morfología urbana y estructura social en la Barcelona contemporánea. El caso de los barrios de la Zona Franca. Tese de doutoramento no Departamento de Geografia, Universitat de Barcelona. Barcelona.

PREVOT-SCHAPIRA, M-F. (2000). Segregación, fragmentación, secesión. Hacia una nueva geografía social en la aglomeración de Buenos Aires. Economía, Sociedad y Territorio, Vol.II, №7.

PREVOT-SCHAPIRA, M-F. (2001). Fragmentación espacial y social: conceptos e realidades. Perfiles Latinoamericanos, n.19, p. 33-56.

PREVOT-SCHAPIRA, M-F. ; PINEDA, R. (2008). Buenos Aires: la fragmentación en los intersticios de una sociedad polarizada. EURE, vol. XXXIV, n.103, p. 73-92.

RYAN-COLLINS, J.; LLOYD, T.; MACFARLANE, L. (2017). Rethinking the economics of land and housing. London: ZedBooks. SANTOS, M. (1990). Metrópole Corporativa Fragmentada: o caso de Sao Paulo. Sao Paulo: Record.

SANTOS, M. (1996). A Natureza do Espaço. Tecnica e Tempo. Razâo e Emoçâo. Sâo Paulo: Record.

SANTOS, M. (2000). Por uma outra globalização. Sâo Paulo: Record.

SASSEN, S. (1991). Global city. New York, London, Tokio. Princeton: Princeton University Press.

SCHMID, C. Networks, borders, differences: towards a theory of the urban. In: BRENNER, N. (2014). ImplosionsExplosions. Towards a study of planetary urbanization. Berlin: Jovis.

Silveira, M.L. (2009). Región y división territorial del trabajo desafíos en el período de la globalización. Investigación y desarrollo, Vol. 17, $\mathrm{N}^{\circ} 2$.

SMITH, N. (1984). Uneven Development: Nature, Capital and the Production of Space. Oxford: Basil Blackwell Publisher. SMITH, N. (1996). The new urban frontier. Gentrification and the revanchist city. London: Routledge.

SPOSITO, M.E.B.; GOES, E. (2013). Espaços fechados e cidades: insegurança urbana e fragmentação socioespacial. São Paulo: Editora da Unesp, v.1. p.365.

SPOSITO, M.E.B. Diferenças e desigualdades em cidades médias no Brasil: da segregação à fragmentação socioespacial. In: XXXVII LATIN AMERICA STUDIES ASSOCIATION, (2019). Boston: LASA2019 Congress Papers, 2019, v. 1. p. 1-25. VIDAL, L. (1995). Les mots de la ville au Brésil. Un exemple: la notion de "fragmentation". Cahiers des Amériques Latines, 
$\mathrm{n}^{0} 18,161-181$

WRIGHT, E. O. (1997). Classes. London: Verso.

WRIGHT, E. O. (2015). Understanding Class. London: Verso.

Acknowledgements

The author wishes to thank Dr. Maria Encarnação Beltrão Sposito, Dr. Carles Carreras i Verdaguer, Dr. Jean Legroux, Marta III Raga and David Creus Expósito for their helpful comments and suggestions. 